\title{
Protecting the Rights of Migrants: The Challenges and the Prospects
}

\author{
Dr. Grace Ayodele Arowolo, \\ Department of Public and Private Law, Faculty of Law, Lagos State University (LASU), Ojo, Lagos. \\ P.O. Box 0001, LASU Post Office, Lagos Badagry Expressway, Ojo, Lagos, Nigeria
}

\begin{abstract}
Migration is a fundamental human process often involving the precarious movement of people across borders. This has implications for human rights. Under the various international human rights laws, human rights are inherent to all human beings and are not tied to one's citizenship or nationality. Therefore, the very presence of all categories of migrants within a State's jurisdiction imposes obligations on the State to acknowledge their presence, and allow them to claim their human rights. Apart from the general human rights laws, other international laws were enacted to specifically protect the rights of many groups of migrants. Despite this, migrants encounter various challenges in the process of migration and in destination countries particularly the migrants that are of irregular status (undocumented migrants). Towards this end, this paper examines the major global international instruments for protecting the human rights of international migrants and the challenges that the migrants often encounter with the aim of identifying the factors responsible for the inadequate protection of migrants' rights. The article proposes that treaty bodies should systematically mandate States' Parties to integrate the specific rights of migrants into national plans of action on human rights, enforce immigration laws in line with the principles of human rights and the rule of law, and provide effective border security and regional engagement so as to discourage illegal migration. Keywords: Migration, Human Rights, Protection, International Framework, Challenges, Prospects.
\end{abstract}

DOI: $10.7176 / \mathrm{JLPG} / 105-12$

Publication date: January $31^{\text {st }} 2021$

\section{Introduction}

The mobility of people across international borders dates back to the creation of borders themselves, and the vulnerability of non-nationals is not a new phenomenon (Mavroudeas, Akar and Dobreva, 2019:32). While many migrants move to take advantage of increased opportunities out of genuine, free and informed choice, many others are compelled to move as a result of poverty, lack of decent work, social exclusion, generalized violence, persecution, human rights violations, armed conflict, xenophobia and environmental degradation (Mavroudeas, Akar and Dobreva, 2019:32). Thus, the World Migration Report of 2018 describes International migration as a complex phenomenon that touches on a multiplicity of economic, social and security aspects affecting our daily lives in an increasingly interconnected world. The report elaborates further that migration is intertwined with geopolitics, trade and cultural exchange, and provides opportunities for States, businesses and communities to benefit enormously while it has also helped improve people's lives in both origin and destination countries and has offered opportunities for millions of people worldwide to forge safe and meaningful lives abroad (McAuliffe and Ruhs, 2017).

This has attracted a rapid increase in the number of international migrants from year to year as asserted in the United Nations (UN) report, that globally, the number of international migrants reached an estimated 272 million in 2019, an increase of 51 million since 2010. Currently, international migrants comprise 3.5 per cent of the global population, compared to 2.8 per cent in the year 2000 (UN DESA, 2019.) While most international migration occurs legally, some of the greatest insecurities for migrants, and much of the public concern about immigration, is associated with irregular migration (McAuliffe and Ruhs, 2017) which takes place when migrants resort to irregular migration channels including seeking out the services of smugglers or even falling prey to traffickers in the absence of regular migration opportunities (Mavroudeas, Akar and Dobreva, 2019:32).

Such irregular migrants often encounter a lot of challenges during migration and in countries of destination. There has also been active reporting in the media of gross human rights violations in the context of migratory phenomena, such as trafficking (in particular in women and children), and the extensive use of irregular migrant labor in the informal economy (Mattila,2000). Migration, therefore, came to be increasingly seen as a high-priority policy issue by many governments, politicians and the broader public throughout the world (McAuliffe and Ruhs, 2017:2). Along with increased attention being given by the international community to human rights issues in general is the specific issue of protecting migrants' rights (both regular and irregular). This points to the global recognition and extension of human rights protection to international migrants. Its premise is that the rule of law and universal notions of human rights are essential foundations for democratic society and social peace (Taran, 2000).

The vast majority of States have ratified international instruments reflecting the principle that all persons, including all migrants irrespective of their migration status, are entitled to have their human rights respected, 
protected, and fulfilled (International Organization for Migration (IOM), 2017) as enshrined in the Universal Declaration of Human Rights (1948) and other basic international human rights laws. Specific global treaties explicitly extending those rights to different groups including international refugees, migrant workers, trafficked and smuggled migrants were also adopted. The treaties include the Convention relating to the Status of Refugees (1951), the Protocol Relating to the Status of Refugees 1967, and the International Convention on the Protection of the Rights of All Migrant Workers and Members of Their Families (ICRMW, 1990).

Other steps taken by the international community to address the challenges of migrants include efforts to improve global migration governance through formal UN mechanisms as well as through informal State-led mechanisms. The efforts include dialogues and consultations held at the global level especially the High-level Dialogue (HLD) on International Migration and Development that held in New York in 2013 and 2016 respectively. Both recognized and reaffirmed the need for international cooperation and action in managing migration and protecting the rights of migrants. The 2016 HLD resulted in the New York Declaration for Refugees and Migrants (UN, 2016) which acknowledged that States have "a shared responsibility to manage large movements of refugees and migrants in a humane, sensitive, compassionate and people-centered manner." Unfortunately, despite these efforts, evidence demonstrates that violations of migrants' human rights are so widespread and commonplace that they are a defining feature of international migration today (Taran,2000:7-52). There are too many instances in which migrants are subjected to violence, abuse, exploitation, discrimination, and other severe human rights violations (International Organization for Migration (IOM), 2017) either limited to the migration journey or experienced while in the country of destination (Global Migration Group, 2008:1-133). This in large part is due not to the absence of international instruments, but includes among others, the lack of the effective implementation of those instruments and appropriate international cooperation (International Organization for Migration (IOM), 2017).

This paper, therefore examines the laws that protect the rights of international migrants in order to identify the extent of protection offered, the challenges often encountered by the migrants, the prospects of migration and recommendations towards better protection of migrants' rights were made. The paper focuses principally on major global-level treaties that provide for general human rights and specific international treaties, dialogues and consultations that protect the rights of migrants.

\section{The Legal and Normative Framework for Global Governance of Migration}

Global governance of migration has been described as a process in which the combined framework of legal norms and organizational structures regulate and shape how States act in response to international migration, addressing rights and responsibilities and promoting international cooperation (Betts, 2011:4-5) including processes such as dialogues and initiatives that have taken place or that relate to governance at the global level (McAuliffe and Ruhs, 2017:137). According to the UN, the concept of governance is important in relation to migration and human rights, not least because migration is a phenomenon involving a wide range of actors including, but not limited to States, but also presents an important counter-balance to the concept of "management" which could be seen as more concerned with control or even containment of migration.

In relation to the protection of the human rights of migrants (regular or irregular), the first principle of IOM's Migration Governance Framework is adherence to international standards and the fulfilment of migrants' rights which requires that:

humane and orderly migration requires compliance with international law. The obligation to respect, protect and fulfil the rights of individuals is paramount and applies to all individuals within a State's territory, regardless of nationality or migration status and without discrimination, in order to preserve their safety, physical integrity, well-being and dignity. Protecting the rights of individuals includes combatting xenophobia, racism and discrimination, ensuring adherence with the principles of equality and non-discrimination, and ensuring access to protection.

The second principle is, "formulating policy using evidence and a whole of government approach" and the third principle is, "engaging with partners to address migration." The objectives are: Advancing the socioeconomic well-being of migrants and society, effectively address the mobility dimensions of crises, and ensure that migration takes place in a safe, orderly and dignified manner.

Stemming from a State's authority over its territory and population, international law recognizes a significant role for unilateral State action in regulating migration (McAuliffe and Ruhs, 2018:125). Although States possess broad powers in this field, (defined by a restrictive conception of national sovereignty), which include authority to determine admission, residence, expulsion and naturalization laws and policies, yet this authority is also constrained by substantive and procedural norms relating to the exercise of State power. States have entered into treaties and agreements, and agreed to customary international law that restrict their authority to regulate migration, as an exercise of their sovereignty and in pursuance of their interests and duties (Aleinkoff, 2001:1-56). This results in a relatively strong track record of international cooperation on a range of issues closely related to the human rights of migrants. These include the global refugee regime, labor migration, and counter-trafficking initiative 
(Office of the High Commissioner for Human Rights, 2012). This implies that although irregular immigrants violate the rules set by the receiving country concerning entry, they do not fall outside the protection obligation set by the host country. It also implies that the laws and norms for migration governance, relevant to the protection of migrants' rights are found in customary international law and diverse instruments, including multilateral treaties, bilateral agreements and domestic laws.

\subsection{Global General Human Rights Instruments on Migrants Rights}

Universal principles of human rights implemented in the rule of law provide the foundation for governance of nations for international migration (Cholewinski and Taran, 2009). Consequently, various States have undertaken significant obligations under international human rights laws towards protecting the rights of individuals and groups, including migrants. These laws impose duties on States to respect, protect and fulfil human rights. The basic document of the modern international human rights regime is the Universal Declaration of Human Rights (UDHR, 1948). The core principle of the international human rights regime is that human rights are universal, indivisible, inalienable, and interdependent. As set forth in the Universal Declaration of Human Rights, migrants are first and foremost human beings, included in the "everyone" language of Article 2:

Everyone is entitled to all the rights and freedoms set forth in this Declaration, without distinction of any kind, such as race, color, sex, language, religion, political or other opinion, national or social origin, property, birth or other status.

The thirty eight articles of the UDHR (particularly articles $3,4,5,11,12,13,17-24$ ), cover a wide range of human rights, including the right to life, liberty and security of person, prohibition of slavery or servitude, prohibition of torture or inhuman or degrading treatment or punishment, right to be presumed innocent until proven guilty, prohibition of retroactive penal legislation, right to respect for private and family life, home and correspondence, right to leave any country and to return to one's own country, right to freedom of thought, conscience and religion, and - right to freedom of expression, right to recognition and equality before the law, public hearing before tribunals, prohibition of arbitrary arrests, detention or exile, right to nationality, the right to marry and found a family, the right to work and social security, and the right to education.

In an attempt to put the rights listed in the UDHR into legally binding instruments, the International Covenant on Civil and Political Rights (ICCPR, 1966) and the International Covenant on Economic, Social and Cultural Rights (ICESCR, 1966), were adopted. These covenants, together with the UDHR constitute the international Bill of Human Rights. Unlike the UDHR, however, both covenants have binding clauses obliging the State Parties to guarantee the rights to all persons within their jurisdiction. While all human rights are applicable to State action on migration, the principle of non-discrimination is among the fundamental rights that impose obligations on States as provided in article 2(1), ICCPR and article 2(2), ICESCR . This principle does not mean all distinctions between citizens and migrants are prohibited. For differential treatment to be permissible, in general, it must be "reasonable and objective" and the overall aim must be "to achieve a purpose which is legitimate" under human rights law (.United Nations Human Rights Committee, 1989). Their application is not restricted to nationals of the ratifying states. All migrants, including irregular ones, are entitled to the protection of these instruments. For example, article 12 of ICCPR provides that persons lawfully within State territory have the right to liberty of movement within the territory and freedom to choose their residence. Everyone is also free to leave any country, including their own, and no one can be arbitrarily deprived of the right to enter their own country. However, under article 22, States are permitted to impose restrictions that are based in law and consistent with the other rights in the Covenant, if the restrictions are necessary to protect national security, public order, public health or morals, or the rights and freedoms of others. This means that States may not arbitrarily deny nationals the right to re-enter. The Human Rights Committee also held that "there are few, if any circumstances in which deprivation of the right to enter one's own country could be reasonable" (Fisher, Martin et. al., 2003:105).

Apart from the international Bill of Human Rights, other core human rights treaties articulate the fundamental importance of safeguarding human dignity. The treaties include the International Convention on the Elimination of All Forms of Racial Discrimination (ICERD, 1965). Articles 2-7 condemn discrimination based on race, color, descent, national or ethnic origin, and provides a list of rights that State Parties should, through their national laws, guarantee to all without discrimination; the Convention on the Elimination of All Forms of Discrimination against Women (CEDAW 1979) and the Convention on the Rights of the Child (CRC, 1989) that both prohibit discrimination against women and children respectively. Others are the Convention against Torture and Other Cruel, Inhuman or Degrading Treatment or Punishment (CAT, 1984) that promotes the prohibition of torture and the infliction of other degrading treatment, and extends the principle of non-refoulement to apply to all cases where there are reasons to believe that a person would be tortured if returned to his or her own country.

Many regional human rights instruments also contain provisions which apply to all individuals, both nationals and non-nationals, within the states. Such regional treaties include the European Convention on Human Rights 1950. This has been described as the first instrument to give effect to certain rights stated in the UDHR and make 
them binding. The African Charter on Human and Peoples' Rights (ACHPR, 1981) in articles 2-12 grants rights to citizens including to equal protection of the law to all without discrimination, prohibits torture, slavery and all forms of degradation. Under article 12 (2) every individual has the right to leave any country including his own and to return to his country subject to restrictions provided by law and for the protection of national security, law and order. Rights of non- nationals not to be expelled subject to decisions taken in accordance with law. The American Convention on Human Rights(1969) also provides in articles 1-26 for the civil and political rights of "every person" without discrimination including right to judicial protection while economic, social and cultural rights is to be realized progressively

Despite the copious provisions for human rights in international law, the extension and practical application of the universal human rights (contained in the international bill of rights and other human rights instruments specified above) to vulnerable groups, migrants inclusive, has been a long and difficult process (Taran, 2000). This is the reason why specific conventions explicitly extending those rights to migrant groups like refugees, migrant workers, trafficked and smuggled victims are elaborated in this paper.

\subsection{Specific Global Instruments for Protecting Migrants' Rights}

The main instruments adopted by the UN are: (a) Convention relating to the Status of Refugees,1951 (b) Protocol Relating to the Status of Refugees, 1967, (c) International Convention on the Protection of the Rights of All Migrant Workers and Members of Their Families, (ICRMW), 1990, (d) Protocol to Prevent, Suppress and Punish Trafficking in Persons, Especially Women and Children, supplementing the United Nations Convention against Transnational Organized Crime, 2000, and (e) Protocol Against the Smuggling of Migrants by Land, Sea and Air, supplementing the United Nations Convention Against Transnational Organized Crime, 2000. These instruments, together with those on the rights of migrant workers adopted by the International Labor Organization (ILO), form the basis of the international normative and legal framework on international migration (UN, 2017)

The 1951 Convention Relating to the Status of Refugee and its Protocol (Refugee Convention) are the principal international instruments established for the protection of refugees (United Nations Office of the High Commissioner for Refugees, 2007). The 1951 Convention is grounded in article 14 of the Universal Declaration of Human Rights 1948, which recognizes the right of persons to seek asylum from persecution in other countries. It is also regarded as the center piece of international refugee protection today and has been subject to only one amendment in the form of the 1967 Protocol, (United Nations Office of the High Commissioner for Refugees, 2007) which removed the geographic and temporal limits of the 1951 Convention. Article 1 (3) of the 1967 Protocol removed these limitations and gave the Convention universal coverage.

The Preamble to the 1951 Convention summarizes the objectives of international protection as: "to assure refugees the widest possible exercise of...fundamental human rights and freedoms" which all "human beings should enjoy....without discrimination as to race, religion or country of origin." The Convention defines the term refugee, enumerates the rights of refugees, and establishes the legal obligation of States to protect refugees. Under article 1 (A) (2) of the Convention, a refugee, is a person who,

... Owing to a well-founded fear of being persecuted for reasons of race, religion, nationality, membership of a particular social group or political opinion, is outside the country of his nationality and is unable or, owing to such fear, is unwilling to avail himself of the protection of that country; or who, not having a nationality and being outside the country of his former habitual residence as a result of such events, is unable or, owing to such fear, is unwilling to return to it.

Articles 3 and 4 of the 1951 Convention requires the contracting States to apply the provisions of this Convention to refugees without discrimination and treat refugees within their territories at least as favorably as States treat their nationals with respect to freedom to practice their religion and freedom as regards the religious education of their children. Article 33 prohibits any form of forcible removal, expulsion or return (refoulment) of any refugee in any manner to the territories where his life or freedom would be threatened on any ground including his race, religion, nationality, membership of a particular social group or political opinion provided the refugee does not constitute a danger to the security of the country in which he is.

The prohibition in article 33 extends to where the refugee is at risk of persecution, interception, rejection at the frontier or indirect refoulement, forcible removal, whether direct or indirect to a threat to life or freedom or to torture, cruel, inhuman or degrading treatment or punishment as also provided in article 5 of the UDHR, 1948. Others are deportation, expulsion, extradition and non-admission at the border (Global Migration Group, 2008). Victims of torture who cross international borders, whether or not they qualify as refugees, can also seek protection on the basis of human rights treaties and customary international law. Despite this provision, many asylum-seekers and even refugees continue to be deported as illegal migrants as part of migration control measures. Asylum-seekers are particularly vulnerable to deportation if detained (Global Migration Group, 2008).

The International Convention on the Protection of the Rights of All Migrants Workers and Members of Their Families (ICRMW, 1990), is regarded as the third and most comprehensive international treaty on migrants' rights. 
It establishes international definitions for categories of migrant workers and formalizes the responsibility of States in upholding the rights of migrant workers and members of their families. The Office of the High Commissioner for Human Rights monitors the implementation of the convention and works to further its ratification. The Convention is complimented by earlier ILO Conventions: Migration for Employment Convention (Revised) (No. C097) 1949 and Convention (No. 143) concerning migration in abusive conditions and the promotion of equality of opportunity and treatment of migrant workers of 1975.

These instruments comprise an international charter on labor migration, providing a comprehensive framework covering most issues of treatment of migrant workers and members of their families (Cholewinski, 2012:1-494). In addition, the ILO's eight fundamental rights conventions recognized as fundamental to the rights of human beings at work as well as ILO instruments of general applicability, such as the Convention Concerning Decent Work for Domestic Workers (ILO Convention No. 189) 2011 are relevant to migrants. The International Convention on the Rights of Migrant Workers, 1990 seeks to secure for migrant workers the rights guaranteed by the UDHR and core human rights treaties (McAuliffe and Ruhs, 2018:132). The convention is applicable to all migrant workers (regular and irregular) and members of their families during the entire migration process which comprises preparation for migration, departure, transit and the entire period of stay and remunerated activity in the State of employment as well as return to the State of origin or the State of habitual residence. Article 2(1) of the ICRMW defines the term migrant worker as: "a person who is to be engaged, is engaged, or has been engaged in a remunerated activity in a State of which he or she is not a national". Articles 1 and 2 prohibits abuses against migrant workers and provides for substantive and procedural safeguards. Article 7 obliges States Parties to respect and to ensure to all migrant workers and members of their families within their territory or subject to their jurisdiction the rights provided for in the present Convention.

Articles 9, 10, 11, 14, and 22 of ICRMW provide for the right to life, prohibition of their subjection to torture or to cruel, inhuman or degrading treatment or punishment or being held in slavery or servitude and performance of forced or compulsory labor, the right to freedom of thought, conscience and religion either individually or in community with others and in public or private, right to manifest their religion or belief in worship, observance, practice and teachings subject only to such limitations as are prescribed by law and are necessary to protect public safety, order, health or morals or the fundamental rights and freedoms of others, right to privacy, family, home, correspondence or other communications prohibition from subjection to measures of collective expulsion which shall be examined and decided individually subject to a decision taken by the competent authority in accordance with law.

Among the key themes covered by ILO Convention No. 97 are the conditions governing the orderly recruitment standards for migrant workers, as well as equal treatment with nationals and lawfully resident migrants in respect of working conditions, trade union membership and enjoyment of benefits including collective bargaining, social security employment taxes and access to justice. Provisions of ILO Convention No. 143 supplementing ILO Convention No. 97 include provisions specifically on migrants in irregular situations. It emphasized that Member States are obliged to respect the basic human rights of all migrant workers, including irregular migrants. It also provided that lawfully present migrant workers and their families should not only be entitled to equal treatment but also to equality of opportunity, such as equal access to employment and occupation, trade union and cultural rights and individual and collective freedoms.

The 2011 ILO Convention Concerning Decent Work for Domestic Workers (ILO Convention No. C189) is also considered relevant to migrant workers. The Convention establishes that domestic workers, regardless of their migration status, have the same basic labor rights as those recognized for other workers. This includes reasonable hours of work, clear information on the terms and conditions of employment, as well as respect for fundamental principles and rights at work, including freedom of association and the right to collective bargaining. Based on challenges that migrant workers encounter, the three international legal instruments specifically designed for the protection of the rights of migrant workers that were just elaborated have largely failed, or at least had very limited success, in protecting migrants in practice. (Ruhs, 2017:1-10). This is primarily because the great majority of highincome countries have refused to ratify and implement these conventions, (in particular the ICRMW) (Ruhs, 2017:1-10). This has resulted in flagrant abuse of the rights of migrant workers.

Two International Protocols regulate the trafficking and smuggling of migrants. Relevant to trafficking is the Protocol to Prevent, Suppress and Punish Trafficking in Persons Especially Women and Children, supplementing the United Nations Convention against Transnational Organized Crime (2000). The threefold purpose of the Protocol are: To prevent and combat trafficking in persons, paying particular attention to women and children; To protect and assist the victims of such trafficking, with full respect for their human rights; and to promote cooperation among States Parties in order to meet those objectives. Article 11 obliges States Parties to strengthen, to the extent possible, "...such border controls as may be necessary to prevent and detect trafficking in persons and adopt legislative or other appropriate measures to prevent, to the extent possible, means of transport operated by commercial carriers from being used in the commission of offences..." Article 7 require States to consider laws or other measures that would allow victims to remain temporarily or permanently on their territory although subject 
to the State's international protection obligations such as those stemming from refugee or human rights law. In spite of this effort, there has been an upward trend in the last decade in the number of victims identified and traffickers convicted globally (United States, Department of States, 2019:6).

Smuggling of migrants is regulated by the Protocol against the Smuggling of Migrants by Land, Sea and Air, supplementing the United Nations Convention against Transnational Organized Crime (2000). The purpose of the Protocol as stated in article 2, is to prevent and combat the smuggling of migrants, as well as to promote cooperation among States Parties to that end, while protecting the rights of smuggled migrants. Article 3, defines "smuggling of migrants" as

the procurement, in order to obtain, directly or indirectly, a financial or other material benefit, of the illegal entry (crossing borders without complying with the necessary requirements for legal entry into the receiving State) of a person into a State Party of which the person is not a national or a permanent resident; or use of fraudulent travel or identity document that has been falsely made or altered in some material way by anyone other than a person or agency lawfully authorized to make or issue the travel or identity document on behalf of a State; or documents improperly issued or obtained through misrepresentation, corruption or duress or in any other unlawful manner; or documents being used by a person other than the rightful holder.

The definition of "smuggled migrants" in article 3 indicates that smuggling of persons across international borders is a means by which irregular migration takes place and is generally viewed as a commercial transaction rather than a situation of vulnerability (McAuliffe and Laczko, 2016:201). Report indicates that migrants are smuggled in all regions of the world despite the law. At a minimum, 2.5 million migrants were smuggled for an economic return of US\$5.5-7 billion in 2016 (United Nations Office on Drugs and Crime (UNODC, 2018: 3).

\subsection{Other Efforts at Improving Global Governance of Migration}

Other efforts to improve global migration governance through formal UN mechanisms as well as through informal State-led mechanisms include (1) dialogues and consultative processes to build confidence and consensus among States; (2) mini-multilateral normative initiatives to enhance protection of migrants; and (3) efforts to ensure that migrants are included in decision-making on other related global issues (McAuliffe and Ruhs, 2018:136).

Key dialogues and consultations held at the global level since 2001, organized by States or the UN, include 2001-2004 Berne Initiative. The goal is to establish a consultative process for an Interconnected World: New Directions for Action (Global Commission on International Migration (GCIM), 2005) laying out a framework for the establishment of coherent responses to the issue of international migration at national, regional and global levels. The UN High-level Dialogue (HLD) on International Migration and Development held in 2006. The objective was to promote the wider application of international and regional instruments and norms relating to migration and to encourage the adoption of more coherent, comprehensive and better coordinated inter-agency approaches.

The 2013 UN High-level Dialogue on International Migration and Development recognized and reaffirmed the need for international cooperation and action in managing migration and protecting the rights of migrants. It obliged Stakeholders to guarantee the protection of the fundamental human rights of all migrants, including labor rights, irrespective of their status; with particular attention to vulnerable groups, such as women, children and migrants caught in crisis situations. The 2016 UN High-level Meeting on Addressing Large Scale Movements of Refugees and Migrants resulted in the adoption of the New York Declaration (UN, 2016). The Secretary General's (SG's) report for the 2016 UN High-level Meeting focused on both refugees and migrants, highlighting trends, causes of large movements, and needs both en route and upon arrival. It called for "new global commitments to address large movements of refugees and migrants, commencing with recommendations to ensure at all times the human rights, safety and dignity of refugees and migrants." The report also elaborated the need to address the causes of movements and protect those who are compelled to move, and to prevent discrimination and counter xenophobia against refugees and migrants (Report of the UN Secretary General, 2016).

The New York Declaration recognized that although there are separate legal frameworks governing refugees and migrants, both have the "same universal human rights and fundamental freedoms and they also face many common challenges and have similar vulnerabilities, including in the context of large movements." In this context, the Declaration endorsed a set of commitments that apply to both refugees and migrants, as well as separate sets of commitments for refugees and for migrants. The Declaration acknowledged that States have "a shared responsibility to manage large movements of refugees and migrants in a humane, sensitive, compassionate and people-centered manner" and to do so through international cooperation, while recognizing that there are varying capacities and resources to respond.

A further major outcome of the 2016 UN High-level Meeting related to institutional arrangements for global migration governance. The New York Declaration condemned xenophobia, racism, racial discrimination, and related intolerance against refugees and migrants, and the stereotypes often applied to them, including on the basis 
of religion or belief and welcomed the Secretary-General's global campaign to counter xenophobia. The Declaration also called for a State-led, consultative process to improve protection and assistance for migrants in vulnerable situations and to give favorable consideration to implementing the recommendations of the Nansen Initiative on cross-border movements in the context of natural disasters and climate change, and the Migrants in Countries in Crisis (MICIC) Initiative. These two initiatives represent what are called mini-multilateral approaches to norm-building to fill gaps in binding international law, particularly ones that are unlikely to be filled by new conventions or treaties (Naim, 2009).

The State-led Nansen Initiative focused on the broad consensus surrounding the need to address the normative gap for the protection of people displaced across borders in the context of disaster, including those related to climate change but including the need to address issues of international cooperation and solidarity. The aim was to develop a more coherent and consistent approach at the international level and help the international community develop an effective normative framework (Martin and Weerasinghe (2017). The main result of the MICIC Initiative was the adoption of the non-binding and voluntary Guidelines to Protect Migrants in Countries Experiencing Conflict or Natural Disaster, launched at the UN in 2016. It provides practical guidance to States, international organizations, private sector actors and civil society on better ways to protect migrants' rights prior to, during, and in the aftermath of conflicts or natural disasters (Migrants in Countries in Crisis (MICIC) Initiative' 2016).

The GMG Principles and Guidelines on the Human Rights Protection of Migrants in Vulnerable Situations within large and/or Mixed Movements (UN Office of the High Commissioner for Human Rights (OHCHR), 2017:1-114) since 2016 has been leading efforts to develop a set of principles and guidelines, supported by practical guidance, on the human rights protection of migrants in vulnerable situations within large and/or mixed movements because the precarious nature of large and/or mixed movements places some migrants in particular situations of vulnerability and they are therefore, in need of specific protection interventions (McAuliffe and Ruhs, 2018:143). These initiatives, consultations and dialogues are non- binding as such States are not under any legal obligation to comply with their provisions.

\section{The Challenges to the Effective Protection of Migrants' Rights}

Despite the elaborate provisions of the UDHR and other general and specific international human rights instruments including global dialogues and consultations all of which emphasize the protection of human rights of citizens, migrants' rights remain inadequately protected. Reports confirm that migrants experience challenges during the migration journey especially at the borders and also in countries of destination upon arrival. Borders have increasingly come to be treated as zones in which immigration control takes precedence over compliance with human rights standards (The Center for Legal and Social Studies (CELS), 2014). Migrants often experience challenges in the following five key areas: deprivation of liberty, denial of Consular Protection, improper handling of Personal Property that are often stolen after seizure from migrants, denial of right to a remedy in the case of human rights violations in border zones, and denial of rights of unaccompanied children who are often treated without regard to their best interests principle or other international law norms relating to children, including automatic detention, removal without due process guarantees and/or a holistic assessment of the risks faced on return ((The Center for Legal and Social Studies (CELS), 2014).

Other key common human rights concerns that shows a pattern of protection gaps and barriers faced by migrants who are in transit and/or at international borders include, (1) criminalization, return and detention; (2) lack of adherence to due process and fair trial guarantees; (3) difficulties in accessing services, including health, information, and legal assistance; (4) lack of adequate child protection systems; and (5) the poor conditions in the facilities, camps and other locations where migrants stay. The report also confirmed the increasing xenophobia, incitement to hatred, and violence against migrants without access to justice and remedies, and weak framework for independent human rights monitoring (Office of the United Nations High Commissioner for Human Rights (OHCHR), 2017). All these contradict the global laws for protecting migrants' rights enumerated in this paper.

Female migrants often face multiple discrimination in the migration process on account of their nationality, immigration or social status as well as gender. Restrictive regulations which give women less chance of migrating legally than men force them to migrate clandestinely. When legal channels are not available, many women and girls see trafficking or smuggling as the only option to cross the border. This places them at increased risk of exploitation and abuse. Girls and women victims of trafficking, refugees, transit and irregular female migrants are most vulnerable to human rights abuse (United Nations Economic Commission for Africa, UNECA-2006-2009).

Responses, such as the arbitrary closure of borders, denial of access to asylum procedures, arbitrary pushbacks, violence at borders committed by State authorities and other actors (including criminals and civilian militias), inhumane reception conditions, and denial of humanitarian assistance, increase the risks to the health and safety of migrants, in violation of their human rights" (United Nations General Assembly, 2018:Para.13). Migrants (especially irregular migrants) are frequently abandoned en route and even at sea, forced into unsafe vessels, and abandoned at destinations they had no intention of going to. According to recent IOM report, 941 migrant fatalities 
were recorded worldwide between January and May, 2020 (International Organization for Migration, 2020). This illustrates that migration governance has not kept pace with the growing impact of international migration, with the result that many migrants face significant rights violations in transit, at their destination, and during or following return (International Organization for Migration, 2020).

Report shows that once at their destination, migrants may continue to face violence, abuse, and other rights violations. Many-regular and irregular migrants also face language barriers, they encounter challenges to integration, and xenophobia. An example is the xenophobic attack on foreigners in South Africa in 2019 with more than 50 mainly foreign-owned shops and business premises, cars and properties destroyed and widespread looting took place (Bloomberg, 2019). Nigerians were greatly affected and many were repatriated. Migrants may also be targeted by unscrupulous employers, landlords, and service providers who take advantage of their limited knowledge of local conditions and reduced bargaining power. Often, irregular migrants are unable or unwilling to access social services due to fear of detection, even if they are legally entitled to them. Given this situation, many migrants who have successfully reached their intended destination remain vulnerable to trafficking and other forms of exploitation (International Organization for Migration, 2017).

At the heart of the dilemma over recognition of migrants' human rights is their vulnerability to exploitation, especially in marginal, low status, inadequately regulated or illegalized sectors of economic activity. Migrant labor has been used in many countries to ensure low cost provision of agricultural produce, to provide domestic service, and to provide services in the "sex industry." Migrants, especially those who are in irregular or unauthorized status, can be considered an ideal reserve of very flexible labor. Those without authorization for entry and or employment are at the margin of protection by labor workplace safety, health, minimum wage and other standards; they often are employed in sectors where such standards are non-existent, non-applicable or simply not respected or enforced (Taran, 2000).

Perspectives from the ILO and the International Confederation of Free Trade Unions (ICFTU) demonstrate that it is often very difficult to organize migrants and immigrants into unions or organizations to defend their interests and rights. When it is not considered illegal under national laws, organizing (especially of those without proper authorization to work) is easily intimidated and disrupted by the threat or actual practice of deportation (Linard, 2004). Migrant workers face undue hardships and abuse in the form of low wages, poor working conditions, virtual absence of social protection, denial of freedom of association and workers' rights, discrimination and xenophobia, as well as social exclusion (International labor Organization (ILO, 2004).

\section{Barriers to Effective Protection of the Rights of Migrants}

i. One of the main challenges to the effective protection of the human rights of migrants is the poor level of ratification, implementation and enforcement of existing human rights instruments. Their de facto extension to many vulnerable groups (particularly migrants) has been a long and difficult process, by no means complete (Appleyard, 2000). Even the specific law for protecting migrant workers (the International Convention on the Protection of the Rights of All Migrant Workers and their Families) suffers from a very low rate of ratification as there are currently only 55 States' Parties to the Convention worldwide.

The bottom line is that the laws lack adequate implementation and enforcement most probably because the human rights laws contain general provisions for the protection of human rights of the people and does not specifically mention migrants but the meaning is just being implied into it by the use of the all-inclusive language "everyone" or "every person" in many of the provisions. The consequence is the mistreatment and flagrant violation of the rights of migrants. According to the office of the United Nations High Commissioner for Human Rights, from a normative perspective, the rights of all migrants receive comprehensive elaboration and thus protection only indirectly by application of general human rights treaties (which recognize that all human beings have rights) or by virtue of treaties which protect sub-groups of migrants, such as refugees or migrant laborers, unfortunately, many of these protections are honored as much in the breach, as they are upheld in the practice of States (Hussein, 2015). Thus, Aleinikoff concludes, "there is both more and less international law than might be supposed" (Aleinkoff, 2003:2).

ii. Furthermore, the laws that were specifically adopted for migrants' rights protection relate to limited categories of migrants like refugees, asylum seekers, migrants' workers, trafficked and smuggled migrants without considering other groups that may not fall within those outlined while noting that many factors can lead to migration. There is a growing consensus that climate change, the evolving nature of conflict, and other crises have and will continue to produce migrants who move as a result of causes that may not be recognized by existing legal categorizations (United Nations High Commissioner for Refugees UNHCR, 2007). An example of migration that falls outside the refugee protection regimes is the concept of "survival migration," that is, movement of migrants who are "outside of their country of origin because of an existential threat to which they have had no access to a domestic remedy or resolution." Others include migration for purposes of family formation and family reunification (Jastram, 2003:185-201) and framework to govern the integration of immigrants (Kalin 2003:271288). 
iii. The current specific laws for migrants' protection enumerated above are not together but contained in scattered documents while the declarations, dialogues and consultations are non-legally binding and so States are not obliged to apply them. This simply portrays that there is no single global law for the protection of migrants' rights yet, that clearly and explicitly enshrines the protection of a core base line of rights (and corresponding set of minimum States' obligations) and applies to all migrants, regardless of the cause of their migration (Kysel, 2010).

iv. Another key obstacle include, the criminalization of illegal entry and the imposition of custodial penalties on migrants who cross borders in an irregular manner. It is of particular concern that migrants prosecuted for such offenses are not provided with the full range procedural safeguards, which are essential to criminal proceedings that may result in a deprivation of liberty, and are subjected to expedited criminal procedures without legal representation (The Center for Legal and Social Studies (CELS).

$\mathrm{v}$. There is no international organization with a mandate to facilitate or manage international migration flows, nor is there an organization with a mandate to protect the human rights of all international migrants (Martin, 2914:12). "As with other issues of a cross-cutting nature, there is no single organization in the international system that has the mandate to provide overall normative oversight and leadership in the protection of migrants' rights" (Office of the United Nations High Commissioner for Human Rights (OHCHR).

\section{The Prospects of International Migration}

Migration is a decision that impacts the welfare of the household, the home community, and in the end the whole economy in various ways (Azam and Gubert, 2006). Among the prospects of international migration especially in developing countries like Africa are: reduction in unemployment, accelerating development in rural areas, infrastructural development, reduction in gender inequality and reducing population pressure in the cities. For the individual migrants, prospects exist such as: better employment with improved income, poverty reduction for migrants and family members, increasing household wealth and expansion of life opportunities including the prospect of sending remittances for family members and for self-development (Agoben, 2018).

Migration has economic, social, and cultural implications for the sending and host societies, remittances the migrants send home are perhaps the most tangible and least controversial link between migration and development (Ratha, 2007). Access to information through the diaspora and the skills learned by returning migrants can improve technology, management and institutions in the sending country, and lower the fixed cost and knowledge requirements for setting up an international business (Carling, 2005). The problems that could be encountered by States of origin especially developing countries like Africa include brain drain, loss of skilled professionals and reduction of labor size in the agricultural sector Agoben, 2018). For the individual migrants, not all impacts are positive. For example, the exploitation of migrants by unscrupulous recruiters or employers is reportedly widespread(Carlin, 2005) including employment and social discrimination (Agoben, 2018), and other challenges enumerated in this paper.

Generally, migrants make huge contributions to both their host countries and countries of origin (Guterres, 2018). They take jobs that local workforces cannot fill, boosting economic activity. Many are innovators and entrepreneurs looking for better lives and work opportunities (Guterres, 2018). With respect to undocumented migrants, the "illegal situation" of such migrant derives from legal rules establishing the right to enter and reside in the country in which he or she is settled (Claude- Valentine, 2004:13). While infringement of such rules is unquestionably an offence, it does not make the individuals concerned criminals or deprive them of their rights. On the contrary, freedom of movement and the choice of place of residence are regarded as fundamental human rights recognized by the Universal Declaration of Human Rights of 1948, the United Nations Charter of 1945 and other human rights instruments. The contradiction is that this "fundamental freedom" clashes with the right recognized to States to decide who is authorized to enter, settle and work in their territory (exercise of State sovereignty) (Claude-Valentine, 2014).

Apart from the foregoing, it has been asserted that the cost of protecting illegal (undocumented) migrants in the destination country is growing at an unsustainable pace (Raley, 2017). Once illegal immigrants successfully gain access into a country, the cost of protecting them automatically falls on the host country even though the country's laws have been violated. The huge expenditure needed to protect illegal immigrants may be justified based on the fact that illegal immigration contributes to the economy of a host country especially through the payment of taxes for services enjoyed by such migrants. For example in the United States of America (USA), undocumented immigrants contribute significantly to state and local taxes, collectively (Gee, Gardener, Hill and Weihe, 2017). In addition, illegal immigration, employment-based permanent immigration, and temporary immigration each tend to provide the U.S. economy with workers who are in scarce supply (Hanson, 2007) while the federal government, also appears to enjoy a net fiscal surplus from immigration (Smith and Barry, 1997) generally.

On the contrary, however, it has been posited that, the amount of taxes illegal immigrants pay is dwarfed by the considerable costs that they impose on American taxpayers thereby refuting the argument that the presence of illegal immigrants in the U.S. is justified because they pay taxes (Raley, 2007). This has made many researchers 
to agree that illegal immigrants are a net cost (United States General Accounting Office (1995); (Mark and Ruark, $2010 ; 8)$. That is, in addition to violating American immigration law, illegal immigrants pay only a fraction of the costs for the services they consume while law abiding taxpayers are stuck footing the vast majority of the fiscal burden created by their actions (Raley, 2007).

\section{Reccomendations}

In view of the foregoing, recommendations are made for the way forward:

a. Granting legal status to all undocumented immigrants present in host countries in order to boost their current state and local tax contributions and allowing them to work legally as part of a comprehensive immigration reform (Gee, Gardner et. al., 2017). This would increase irregular (undocumented) migrants' state and local tax contributions (Gee, 2017).

b. Legalization could also be done through two means, first is a rolling legalization process which allows longterm illegal immigrant residents to legalize their status on an ongoing basis without an applicable cut-off date, This involves a suspension of deportation policy for any illegal immigrant although it only applies to long term residents and not recent arrivals. The second is slowing chain immigration by limiting legalized immigrants' ability to sponsor family members from overseas for lawful permanent residency (LPR) or green cards. (Nowrasteh and Bier, 2019). These methods would grant legal work and residency status to illegal (irregular) immigrants who are already in the country if they are not a menace to public safety and would increase immigration enforcement to deter future illegal immigrants from coming into foreign countries or overstaying visas (Nowrasteh and Bier, 2019). c. There should be effective border security and regional engagement, enforcing immigration laws, and legal immigration reform (Carafano, 2019) in line with the principles of international human rights laws and the rule of law.

$\mathrm{d}$. There is need for a comprehensive binding instrument that seeks to incorporate the current treaties, declarations, dialogues and consultations that protect all migrants, regardless of the cause of their movement across an international borders and at destination countries. Such law should include policy and action addressing migration and integration need to cover administration of immigration, legal protection measures, labor market regulation, labor inspection, social protection, health, education, housing, police protection, and much more. An array of measures is needed to prevent abusive practices and promote decent and productive work for women and men migrants in conditions of freedom, equity, security, and human dignity. This is all the more so in these disruptive times of economic crisis (Cholewinski and Taran 2009).

e. Based on the New York Declaration, obligations are imposed on States to acknowledge the presence of migrants (regardless of their status) whenever in their territories, and allow them to claim their human rights (UN Committee on Economic, Social and Cultural Rights, 2017: Para. 11). More specifically, States are obliged to respect, protect and fulfil the human rights of all migrants on their territory. Failure to perform this obligation should be attached with sanctions.

f. States must ensure non-discriminatory access of migrants to economic, social and cultural rights and associated services. The International Covenant on Economic, Social and Cultural Rights (ICESCR) recognizes the rights to health, education, social security, decent work, and an adequate standard of living including housing for all people. A Country/State that is constrained by a lack of resources still has a duty to take deliberate, concrete and targeted steps towards meeting obligations, including concrete actions to protect the most disadvantaged or marginalized groups in society such as migrants in irregular situations (UN Committee on Economic, Social and Cultural Rights, 2019). Although this should be to the extent possible especially for irregular migrants.

g. All migrants should be allowed to claim their rights, including by reporting discrimination, violence, hate crimes, and other abuse without fear of repercussions regarding their migration status, such as being identified, arrested and detained. Such measures allow specific departments to carry out their duties effectively, and with the wider community in mind, such as allowing people to safely report crimes to police officers, and to seek medical treatment before health conditions become chronic (United Nations Office of the High Commissioner).

$h$. End the use of detention as a migration management tool. Its use in the context of migration must be consistent with the non-derogable prohibition of arbitrary detention, which requires the measure to be strictly necessary and proportionate to a legitimate State aim, and accompanied by full due process guarantees. States should, therefore, end the criminalization of irregular migration and work to end all immigration detention by implementing noncustodial, community-based alternatives to detention that fully protect and respect the human rights of irregular migrants (United Nations Office of the High Commissioner). The Committee on the Rights of the Child has highlighted that "the detention of any child because of their or their parents' migration status constitutes a child rights violation and contravenes the principle of the best interests of the child. See the UN Committee on the Rights of the Child, Joint General Comment No. 23 (2017) on State obligations regarding the human rights of children in the context of international migration in countries of origin, transit, destination and return (UN Committee on the Rights of the Child, 2017).

i. Decriminalize irregular migration as it results in multiple negative human rights impacts as elaborated in the 
case of Velez Loor v Panama (Judgement (IACtHR) $23^{\text {rd }}$ November, 2010), Paras. 143-162). This can be achieved by amending legislation to ensure that leaving, and/or staying in a country irregularly is not considered a criminal offence (United Nations Office of the Human Rights Commissioner, 2017) in accordance with International human rights standard which states that crossing or attempting to cross the border of a country in an unauthorized manner or without proper documentation, or overstaying a permit of stay should not constitute a crime: while irregular entry and stay may constitute administrative offences, they are not crimes per se against persons, property and national security (Special Rappoteur on the Human Rights of Migrants, 2012). Proportionate, necessary and reasonable administrative sanctions should be applied (United Nations Office of the Human Rights Commissioner). This enhances the implementation of the New York Declaration for Refugees and Migrants to consider reviewing policies that criminalize cross border movement.

In paragraph 33 of the Declaration, member States unanimously reaffirmed their commitment to fully protect the human rights of all refugees and migrants as rights-holders, regardless of their status, and to devise comprehensive responses that will demonstrate full respect for international human rights law and other relevant standards. It reflects States' continued commitment to the core international human rights treaties in relation to their migration governance measures. The High Commissioner has repeatedly maintained that, "desperate people who are left with no regular migration options will continue to risk their lives in search of safety and dignity" (United Nations High Commissioner for Human Rights, 2016). Criminalization due to migrants' status or inability to arrive regularly will not serve as an effective deterrent and even less as an appropriate migration governance measure (United Nations High Commissioner for Human Rights, 2016).

Consequent upon this, the UN General Assembly in 1975 requested UN organs and agencies to use the terms nondocumented and irregular migrant workers instead of terms like "illegal migrant worker" UN General Assembly, Resolution. Since that time, other international bodies have made a point of using these terms to avoid the stigma attached to terms such as "illegal migrant."

j. Ensure that adequate procedural safeguards are made available to migrants regarding deportation decisions, including the provision of justification for a removal order in writing in a language and format the migrant can understand, the provision of information on the remedies available, legal assistance and time to challenge the decision, and automatic suspensive effect of a removal order until the case has been determined and ensuring the right to a fair trial to migrants imprisoned on criminal charges due to the criminalization of irregularity in national law (Kysel, 2010).

$\mathrm{k}$. Governments to put in place more legal pathways for migration, thus removing the incentives for individuals to break the rules, while better meeting the needs of their labor markets for foreign labor. This is to prevent incidences of irregular migration and the associated negative impacts. The more opportunities there are for regular channels of migration, the less will be the incentive for trafficking of people, exploitation and serious abuse of migrants in the countries of origin, transit and destination (Global Migration Group, 2008). In fact, to be sustainable, international migration laws and policies must address a wide range of issues, including but not limited to the legal channels for migration of persons seeking work opportunities in other countries and protection of the rights of migrants and their families, including persons who have been smuggled or trafficked (Martin, 2005).

1. Governments of States of origin of migrants have a lot of duties to perform to prevent migration especially forced/irregular migration. This is because most of the factors leading to migration often result from the failure of migrants' States of origin to perform their duties as nations towards their citizens. Causes of migration in Africa for example, have been attributed to population pressure, communal, ethnic and criminal violence, poverty, political strife and corruption (Jaiteh, 2018; United Nations, Department of Economic and Social Affairs, 2020). Corruption has been identified as the major obstacle to economic, political, and social development of the African continent generally (Adegbite, 2012). In many African countries for example, due to corruption, relative wealth has not been equitably distributed in the population while the subsequent world economic crisis since 2011 has slowed down the economic performances of most African countries to a bare 2\% yearly GDP increase (Castelli, 2018). As a result, most jobs in developing countries are still in the informal sector, with little salary and social protection, low performances in the health, education and economic sector, thus encouraging citizens' search for better job and better life conditions elsewhere (Castelli, 2018).

It is the duty of the States of origin to develop a multifaceted approach that involves various sectors of the economy. This will enable economic growth and development that will cut down the poverty level and enable the provision of welfare benefits to citizens generally. Thus, discouraging migration.

\section{Conclusion}

Analysis in this paper has shown that implementation of the legal and normative framework on migrants' rights is greatly challenged. This is the reason why they were characterized as a fragmented tapestry at the bilateral, regional, inter-regional, and multilateral levels, which vary according to different types of migration (Betts, 2011). The paper also shows the unabated violation of the rights of migrants. A stronger States' co-operation within the global governance and a well regulated comprehensive law with stringent penalties for defaulters at the international level 
is required. In addition, it is essential that States maintain appropriate services to deal with issues of international migration by formulating and implementing migration policies as well as exchanging information, consult and cooperate with the competent authorities of other States (Global Migration Group, 2008). States of origins have the duty to provide for its citizens. A more expansive concept of government as provider is the social welfare state: government can cushion the inability of citizens to provide for themselves, particularly in the vulnerable conditions of youth, old age, sickness, disability and unemployment due to economic forces beyond their control (Slaughter, 2017). The overall responsibility of the State includes ensuring the due provision of benefits according to clear and transparent eligibility criteria and entitlements, and the proper administration of the institutions and services. Where benefits and services are not provided directly by public institutions, the effective enforcement of the legislative frameworks is particularly important for the provision of benefits and services (Social Protection and Human Rights, 2015). It is hoped that if the recommendations in this paper are implemented, violation of the rights of migrants will be ameliorated while the rate of migration will be reduced.

\section{References}

Adegbite, F.F.and Fakile, A.S. (2012). Economic and Financial Crime in Nigeria: Forensic accounting as antidote. British Journal of Arts and Social Sciences, 6 (1), 37-50.

African Charter on Human and Peoples' Rights (ACHPR) (1981), CAB/LEG/67/3 rev. 5, 21 I.L.58 (1982)

Agoben T, (2018), "Migration in Africa - Who Gains and Who Lose? The Prospects and Problems of Migration in Africa: For the Migrant and the African Continent" Research and Reviews: Journal of Social Sciences (JSS), 4 (3) 343-359.

Aleinikoff, T, "International Legal Norms and Migration: A Report," in Aleinikoff, T., and Chetail, V (eds.), Migration and International Legal Norms, (The Hague: T.M.C. Asser Press, 2003) p. 2.

Aleinkoff T, A., "International Legal Norms and Migration: An Analysis", (Geneva: International Organization for Migration, 2002) pp. 1- 56.

American Convention on Human Rights, "Pact of San Jose", Costa Rica, 1969.

Appleyard, R (ed.), "The Human Rights of Migrants", International Organization for Migration (IOM), Offprint of International Migration Vol. 38 (6) Special Issue 3/2000, (Co published by International Organization for Migration (IOM and United Nations, 2001) pp.3-5.

Azam, J. and Gubert, F., (2006), "Migrants' Remittances and the Household in Africa: A Review of the Evidence" Journal of African Economies, 15, 426-462.

Betts A (ed.), Global Migration Governance, (Oxford: Oxford University Press, 2011) pp. 4-5.

Carafano, J. J., (2019) "4 Ways Trump Can Fix America's Immigration Problem," https://www.heritage.org/immigration/commentary/4-ways-trump-can-fix-americas immigration-problem

Carling, J, (2005) "Migrant Remittances and Development Cooperation, PRIO Report 1/2005", International Peace Research Institute, Oslo (PRIO), 2005. Oslo.

Castelli, F., Drivers of Migration: Why do People Move? Journal of Travel Medicine, 2018, 1-7.

Cholewinski, R and Taran, P, (2009), "Migration, Governance and Human Rights: Contemporary Dilemmas in the Era of Globalization," Refugee Survey Quarterly, 28 (4) 1-33.

Cholewinski, R, "International labour migration", in Opeskin, B., Perruchoud, R and Redpath-Cross, J, (eds.)., Foundations of International Migration Law, (Cambridge: Cambridge University Press, 2012) pp.1-494.

Convention against Torture and Other Cruel, Inhuman or Degrading Treatment or Punishment 1984 (CAT). UN General Assembly resolution 39/46 of 10 December 1984.

Convention on the Elimination of All Forms of Discrimination against Women (CEDAW) 1979. UN General Assembly resolution 34/180 of 18 December 1979.

Convention for the Protection of Human Rights and Fundamental Freedoms, 1950.

Convention on the Rights of the Child (CRC), 1989. UN General Assembly Resolution 44/25, 1989.

Convention relating to the Status of Refugees, 1951. UN General Assembly Resolution 429(V) of 14 December 1950.

Fisher, D, Martin, S and Scheonholtz, A, "Migration and Security in International Law", in Aleinikoff, T. A., and Chetail, V. (eds), Migration and International Legal Norms (The Hague: Asser Press, 2003), p.105.

Gee, L. C., Gardner, M., Hill, M.E., and Wiehe, E., (2017), “Undocumented Immigrants' State \& Local Tax Contributions" Institute on Taxation \& Economic Policy (ITEP) pp. 1-38

Global Migration Group, (2010), "International Migration and Human Rights: Challenges and Opportunities on the Threshold of the 60th Anniversary of the Universal Declaration of Human Rights," Global Migration Group, pp. 1-133.

Hanson, G. H., (2007) “The Economic Logic of Illegal Immigration”, CSR NO. 26, April 2007, Council on Foreign Relations, pp. 1-34.

High-level Dialogue (HLD) on International Migration and Development, General Assembly Resolution (A/RES/68/4), 2013 
Hussein, Z, (2015), “Opening Statement by Mr. Zeid Ra'ad Al Hussein, United Nations High Commissioner for Human Rights to a Panel to Mark the 25th Anniversary of the Adoption of the Convention on the Protection of the Rights of All Migrant Workers and Members of their Families," September 8. Geneva: OHCHR.http://www.ohchr.org/EN/NewsEvents/Pages/DisplayNews.aspx?NewsID=16397\&LangID= E\#sthash.u8i9PL32.dpuf. Accessed $27^{\text {th }}$ November, 2019,

International Convention on the Elimination of All Forms of Racial Discrimination (ICERD), (1965), UN General Assembly resolution 2106 (XX) of 21 December 1965.

International Convention on the Protection of the Rights of All Migrant Workers and Members of Their Families (ICRMW). UN General Assembly Resolution 45/158 of 18 December 1990.

International Covenant on Civil and Political Rights, 1966, UN General Assembly Resolution 2200A (XXI) on 16 December 1966.

International Covenant on Economic, Social and Cultural Rights (ICESCR), UN General Assembly Resolution 2200A (XXI) of 16 December 1966. 170 States' Parties.

International Labour Organization (ILO), Migrant Workers (Supplementary Provisions) Convention, C143, 24 June 1975, C143.

International Labour Organization (ILO), Migration for Employment Convention (Revised), C97, 1 July 1949, C97.

International Labour Organization (ILO), (2004), "Towards a Fair Deal for Migrant Workers in the Global Economy", Report VI International Labour Conference, 92nd Session, (1st ed, International Labour Office Geneva, 2004) pp. 46-48.

International Organization for Migraton (IOM) (2017) "Contribution to the fifteenth Coordination Meeting on International Migration," Department of Economic and Social Affairs United Nations Secretariat, New York, UN/POP/MIG-15CM/2017/15, 2017. International Organization for Migration (IOM), Migration Governance Framework (MiGOF), Council Resolution 1310.

International Organization for Migration (IOM), Protection of the Human Rights and Fundamental Freedoms of Migrants and the Specific Needs of Migrants in Vulnerable Situation, https:// www. iom. int/ site/ default/ files/our_ work/ODG/GCM/IOM-Thematic-Paper-Protection -of-Human-Rights-andVulnerableMigrants.pdf. Accessed 23 ${ }^{\text {rd }}$ March, 2020.

Jaiteh L., The Gambia: Desperate Young take the Backway to an Uncertain Future, 2018, https:// ethicaljournalismnetwork.org/resources/publications/moving-stories/west-africa. Accessed 1st August, 2020.

Jastram, K, Jastram "on Family Unity”, in Aleinikof, A and Chetail, V (eds.), Migration and International Legal Norms, (The Hague: Asser Press, 2003) 185-201.

Kälin, W, (2012), "From the Nansen Principles to the Nansen Initiative." Forced Migration Review 41 48-49.

Kälin, W, "Human Rights and the Integration of Migrants," in Aleinikoff, T and Chetail, V (eds), Migration and International Legal Norms, (Asser Press, The Hague, The Netherlands, 2003) pp. 271-288

Kysel, M, (2010), "Promoting the Recognition and Protection of the Rights of All Migrants Using a Soft-Law International Migrants Bill of Rights" Georgetown Immigration Law Journal 24, 533-52.

Linard, A, (1998), "Migration and Globalisation : The New Slaves," (International Confederation of Free Trade Unions, Brussels, 1998). Cited in Bogusz, B, Cholewinski, R, Cygan, A., (eds.), Irregular Migration and Human Rights: Theoritical, European and International Perspectives (Leiden Boston: Martinus Nihjoff Publishers, 2004) p. 275.

Mattila H, (2000), "Protection of Migrants' Human Rights: Principles and Practice," Journal of International Migration, 38 (6), 53-7.

Mark, J., and Ruark, E. A., (2010), "The Fiscal Burden of Illegal Immigration on the United States Tax Payers", Federation for American Immigration Reform (FAIR) Report, p. 8.

Martin, S. and S. Weerasinghe (2018), "Global Migration Governance: Existing Architecture and Recent Developments' in International Organization for Migration (IOM)" (2017) World Migration Report, Geneva: IOM, p. 16.

Martin, S, "International Migration: Evolving Trends from the Early Twentieth Century to the Present," (New York: Cambridge University Press, 2014) pp. 1-2.

Martin, S, “The legal and Normative Framework of International Migration,” (Global Commission on International Migration 2005) pp. 1-42.

Mavroudeas, S., Akar, S., and Dobreva, J., (eds.), Globalization, Poverty, Inequality and Sustainability, (Istanbul; IJOPEC, 2019), p.32.

McAuliffe, M and Laczko, F (eds.), "Migrant Smuggling Data and Research: A Global Review of the Emerging Evidence Base", (International Organization for Migration, Geneva, 2016) p.201.

McAuliffe, M and Ruhs, M (eds.), "World Migration Report 2018," (International Organization for Migration, Geneva, Switzerland, 2017) p. 1.

Naim, M, (2009), "Minilateralism: The Magic Number to Get Real International Action,” Foreign Policy, 173, 
135-136.

New York Declaration for Refugees and Migrants (UN, 2016) Adopted by General Assembly Resolution A/RES/71/1 of 3rd October 2016,

Nowrasteh, A. and Bier, D., "Three New Ways for Congress to Legalize Illegal Immigrants," Immigration Research and Policy Brief No. 12), April10, 2019, https://www.cato.org/ publications/immigration-researchpolicy-brief/three-new-ways-congress-legalize-illegal-immigrants. Accessed $10^{\text {th }}$ June 2019.

Office of the United Nations High Commissioner for Human Rights (OHCHR), (2013), "Migration and Human Rights: Improving Human-Rights Based Governance of International Migration.” http://www.ohchr.org/ Documents/ Issues/ Migration/ MigrationHRimprovingHR Report.pdf. Accessed $7^{\text {th }}$ January, 2020,

Protocol Relating to the Status of Refugees 1967 Adopted by UN General Assembly Resolution 2198 (XXI) of 16 December 1966

Protocol to Prevent, Suppress and Punish Trafficking in Persons, Especially Women and Children, supplementing the United Nations Convention against Transnational Organized Crime, 2000Adopted by UN General Assembly Resolution 55/25 of 15 November, 2000.

Raley, S., "The Hill”, (2017), https://thehill.com/blogs/congress-blog/homeland-security/ 352869-the-cost-ofillegal-immigration-to-taxpayers-is-growing...Accessed $8^{\text {th }}$ December, 2019.

Ratha, D, (2007), "Leveraging Remittances for Development" (Policy Brief), (Washington D.C: Migration Policy Institute), 173-185.

Ruhs, M, (2017), "Protecting Migrant Workers: The Case for a Core Rights Approach", in McAuliffe, M., and Klein S, Ideas to Inform International Cooperation on Safe, Orderly and Regular Migration, (Geneva: International Organization for Migration, 2017) pp.1-10,

Sironi, A, Bauloz, C and Emmanuel, M (eds.), (2019), International Migration Law: Glossary on Migration No. 34 (Geneva: International Organization for Migration, 2019) p.130.

Slaughter, A. M., 3 Responsibilities Every Government has Towards its Citizens, https://www. weforum.org/agenda/ 2017/02/government-responsibility-to-citizens-anne-marie-slaughter. Accessed 31st July, 2020.

Social Protection and Human Rights, (2015), https://socialprotection-humanrights.org/. Accessed 31st July, 2020

Taran P, (2000), "Human Rights of Migrants: Challenges of the New Decade" International Migration 38, (6), 752.

UN Committee on the Rights of the Child, Joint General Comment No. 23 (2017) on State obligations regarding the human rights of children in the context of international migration in countries of origin, transit, destination and return, 16 November 2017, CMW/C/GC/4-CRC/C/GC/23, para 5.

United Nations, Department of Economic and Social Affairs, Population Division (2017). International Migration Report 2017: Highlights (ST/ESA/SER.A/404), pp.1-24.

United Nations, Department of Economic and Social Affairs, Population Division (2020). World Population Policies 2019: Highlights (ST/ESA/SER.A/443).

United Nations, Department of Economic and Social Affairs (UN DESA), "The number of international migrants reaches 272 million, continuing an upward trend in all world regions, says UN" (2019), https://www.un.org/ development/desa/en/news/population/ international-migrant-stock-2019.html. Accessed 29th May, 2020.

United Nations High Commissioner for Refugees (UNHCR), 2007. "Refugee Protection and Mixed Migration: A 10-Point Plan of Action.” Geneva: UNHCR. http://www.unhcr.org/ 4742a30b4.html/.

United Nations (UN) Office of the High Commissioner for Human Rights (OHCHR), Migration and Human Rights: Improving Human Rights-Based Governance of International Migration, (Geneva: UN, OHCHR, 2012).

United States General Accounting Office, Washington, D. C., (1995) "Illegal Aliens: National Net Cost Estimates Vary Widely. GAO REP. NO. 133, July25, 1995, P.2;

United Nations Office of the High Commissioner for Refugees (UNHCR). (2007). Introductory Note by the United Nations Office of the High Commissioner for Refugees. Convention and Protocol Relating to the Status of Refugees, General Assembly Resolution 428 (V) of 14 December 1950

Universal Declaration of Human Rights. Adopted by General Assembly Resolution 217A.UN DOC.A/810, 